\title{
Effect of Fly Ash and Farm Yard Manure on Yield of Rice and Physical Properties of Soil
}

\author{
T. Prabhakar Reddy*, D. Vijaya Lakshmi, J. Kamalakar and M. Uma Devi \\ Regional Sugarcane and Rice Research Station, Rudrur, Nizamabad, Telangana, India \\ *Corresponding author:
}

\section{A B S T R A C T}

\section{Ke ywords}

Fly ash, FYM,

Rice, yield,

Cracking pattern, Aggregate stability.

Article Info

Accepted:

24 January 2017

Available Online:

10 February 2017
A Field experiment was conducted in a fine loamy mixed Hyperthermic Typic Haplustept soil to study the effect of fly ash and FYM on yield of rice and on cracking pattern of soil. The grain and straw yield of rice was significantly increased with fly ash, FYM and their interactions. The highest grain $\left(5.84 \mathrm{tha}^{-1}\right)$ and straw yields $\left(7.87 \mathrm{t} \mathrm{ha}^{-1}\right)$ were recorded by combined application of fly ash at $10 \mathrm{t} \mathrm{ha}^{-1}$ and FYM at $10 \mathrm{tha}^{-1}$ which was on par with fly ash at $15 \mathrm{t} \mathrm{ha}^{-1}$ along with FYM at $10 \mathrm{tha}^{-1}$. Application of fly ash and FYM has resulted in lesser number of cracks with more width and depth when compared to control. Study of cracking pattern of the field after crop harvest indicated that the number of cracks $\left(29.33 \mathrm{~m}^{-2}\right)$ were lowest and the width of cracks $(3.67 \mathrm{~cm})$, depth of cracks $(10.57$ $\mathrm{cm})$ were highest in $\mathrm{FA}_{15} \mathrm{FYM}_{10}$ followed by $\mathrm{FA}_{10} \mathrm{FYM}_{10}\left(38.67 \mathrm{~m}^{-2}, 2.87 \mathrm{~cm}, 8.7 \mathrm{~cm}\right.$, respectively) when compared to control $\left(\mathrm{FA}_{\mathrm{o}} \mathrm{FYM}_{\mathrm{o}}\right)\left(96.67 \mathrm{~m}^{-2}, 0.78 \mathrm{~cm}, 3.57 \mathrm{~cm}\right.$, respectively). The aggregate stability studied in terms of per cent aggregates $>0.25 \mathrm{~mm}$ in diameter (55.60) and mean weight diameter (1.7) were highest in $\mathrm{FA}_{15} \mathrm{FYM}_{10}$ followed by $\mathrm{FA}_{10} \mathrm{FYM}_{10}$ (53.40 and 1.95 respectively) when compared to control (43.63 and 1.79, respectively).

\section{Introduction}

Fly ash is formed from burning of pulverized coal at electric power generating plants. Finding local outlets for sufficient quantities of fly ash often create problem of disposal. One of the ways of effective utilization of fly ash could be its use as a soil amendment and as a source of plant nutrients. Physically fly ash occurs as very fine particles, having an average diameter of $<10 \mathrm{~mm}$, low to medium bulk density, high surface area and very light texture. Chemically the composition of fly ash varies depending on the quality of coal used and operating conditions of thermal power stations (Sahoo and Kar, 1998). Approximately on an average 95 to 99 percent of fly ash consists of oxides of $\mathrm{Si}, \mathrm{Al}, \mathrm{Fe}$ and $\mathrm{Ca}$ and about 0.5 to 3.5 per cent consists of $\mathrm{Na}, \mathrm{P}, \mathrm{K}$ and $\mathrm{S}$ and the remainder of the ash composed of trace elements.

Rice plays a pivotal role in Indian economy being the staple food for two thirds of the population. In India, it is grown in an area of 42.2 million hectares with a production of 91.0 million tones and productivity of 2154 $\mathrm{kg} \mathrm{ha}{ }^{-1}$, while in Andhra Pradesh it is grown in an area of 39.8 lakh hectares with a production of 117.0 lakh tones and productivity of $2939 \mathrm{~kg} \mathrm{ha}^{-1}$. 
The crack size and spacing that is their network in the field indicates the hydrodynamics properties of soil. Study on cracking pattern is a simple test which indicates the general swell shrink behaviour of the soil. During fallow phase of cultivation cracking pattern decides the water loss from the soil mass particularly from the deeper layers. The present investigation was under taken to study the integrated effect of fly ash and FYM on yield of rice and on cracking pattern of soil.

\section{Materials and Methods}

A field experiment was conducted in a fine loamy, mixed Hyperthermic Typic Haplustept soil at College farm, Department of Soil Science and Agricultural Chemistry, College of Agriculture, Acharya N.G. Ranga Agricultural University, Rajendranagar. The experiment comprised of eight treatment combinations with four levels of fly ash $(0,5$, 10 and $\left.15 \mathrm{t} \mathrm{ha}^{-1}\right)$ and two levels of FYM (0 and $10 \mathrm{t} \mathrm{ha}^{-1}$ ). Fly ash and FYM applied as per the treatments before transplanting the rice. All the plots have received the common doses of NPK fertilizers (120-60-40 kg ha ${ }^{-1}$ ). The rice var. Tellahamsa was used as the test crop.

The fly ash was collected from National Thermal Power Corporation (NTPC), Ramagundam, Andhra Pradesh. It contained the nutrients like $\mathrm{N}\left(27.5 \mathrm{mg} \mathrm{kg}^{-1}\right), \mathrm{P}_{2} \mathrm{O}_{5}(29.6$ $\left.\mathrm{mg} \mathrm{kg}{ }^{-1}\right), \mathrm{K}_{2} \mathrm{O}\left(110.5 \mathrm{mg} \mathrm{kg}^{-1}\right), \mathrm{S}\left(25.4 \mathrm{mg} \mathrm{kg}^{-}\right.$ $\left.{ }^{1}\right), \mathrm{Ca}\left(7.25 \mathrm{mg} \mathrm{kg}^{-1}\right), \mathrm{Mg}\left(2.20 \mathrm{mg} \mathrm{kg}^{-1}\right), \mathrm{Fe}$ $\left(17.50 \mathrm{mg} \mathrm{kg}^{-1}\right), \mathrm{Mn}\left(3.34 \mathrm{mg} \mathrm{kg}^{-1}\right), \mathrm{Cu}(0.98$ $\left.\mathrm{mg} \mathrm{kg}^{-1}\right), \mathrm{Zn}\left(1.83 \mathrm{mg} \mathrm{kg}^{-1}\right)$. The texture of fly ash was silty loam with $\mathrm{pH} 8.1$ and EC 0.37 $\mathrm{dS} \mathrm{m}{ }^{-1}$. The experimental soil was sandy clay loam in texture, slightly alkaline in reaction (pH 7.9), non saline (EC $0.29 \mathrm{dS} \mathrm{m}^{-1}$ ), low available $\mathrm{N} \quad\left(210 \quad \mathrm{~kg} \quad \mathrm{ha}^{-1}\right), \quad$ available phosphorus $\left(8.7 \mathrm{~kg} \mathrm{P}_{2} \mathrm{O}_{5} \mathrm{ha}^{-1}\right)$, medium in available potassium $\left(180 \mathrm{~kg} \mathrm{~K}_{2} \mathrm{O} \mathrm{ha}{ }^{-1}\right)$, and sufficient in micronutrient status (Fe $8.62 \mathrm{mg}$ $\mathrm{kg}^{-1}$, Mn $5.56 \mathrm{mg} \mathrm{kg}^{-1}$, Cu $1.09 \mathrm{mg} \mathrm{kg}^{-1}$ and $\mathrm{Zn} 1.05 \mathrm{mg} \mathrm{kg}^{-1}$ ).

Grain and straw yields of rice were recorded at harvest. Effect of different levels of fly ash and FYM on cracks distribution pattern was studied about one month after harvest of the rice crop and evaluated in terms of number of cracks per $\mathrm{m}^{2}$, width of cracks and depth of cracks. Soil samples were collected from 0 to $15 \mathrm{~cm}$ depth in each sub plot after the harvest of the crop. The composite samples were analyzed for water stable aggregates (Aggregates > $0.25 \mathrm{~mm}$ in diameter) by Yoders Wet Sieving method (Kemper and Chepil, 1965). Mean weight diameter was worked out as per the formulae given by Van Bavel (1949).

\section{Results and Discussion}

\section{Yield of rice}

Fly ash, FYM and their interactions showed significant influence on grain and straw yield of rice (Table 1). The highest grain yield was recorded by $\mathrm{FA}_{10} \mathrm{FYM}_{10}\left(5.84 \mathrm{tha}^{-1}\right)$ which was on par with $\mathrm{FA}_{15} \mathrm{FYM}_{10}$ and has recorded about 21 per cent higher grain yield over control $\left(\mathrm{FA}_{\mathrm{o}} \mathrm{FYM}_{\mathrm{o}}\right)\left(4.82 \mathrm{t} \mathrm{ha}^{-1}\right)$. Similarly the increase in grain yield of rice due to application of fly ash was reported by Arvind Kumar et al., (1998) and Jayabal et al., (2000). The highest straw yield was reported by $\mathrm{FA}_{10} \mathrm{FYM}_{10}\left(7.87 \mathrm{tha}^{-1}\right)$ which was on par with $\mathrm{FA}_{15} \mathrm{FYM}_{10}$ and has recorded about 17.8 per cent higher straw yield over control (FAo FYMo) $\left(6.68 \mathrm{t} \mathrm{ha}^{-1}\right)$. The results obtained are in confirmation with those obtained by Arvind Kumar et al., (1998), Mongia et al., (2003).

The supply of nutrients, conducive to physical environment leading to better aeration, root activity and nutrient absorption and the 
consequent complementary effect would have resulted in higher grain and straw yield of rice (Selvakumari et al., 2000).

\section{Cracking pattern of soil}

The number of cracks per $\mathrm{m}^{2}$ and mean width of cracks after the rice crop harvest was significantly influence by fly ash levels, FYM and their interaction where as depth of cracks was not significantly influenced by FYM application (Table 2, Fig. 1 and 2). The control treatment (FAo FYMo) has recorded maximum number of cracks per $\mathrm{m}^{2}$ (96.67).

Table.1 Effect of fly ash and FYM on grain and straw yields of rice (Var. Tellahamsa) (t ha-1)

\section{Grain yield (t ha $\left.{ }^{-1}\right)$}

\begin{tabular}{|l|c|c|c|}
\hline \multirow{2}{*}{\begin{tabular}{c} 
Fly ash levels $\begin{array}{c}|c| \\
\left.\mathrm{ha}^{-1}\right)\end{array}$ \\
\cline { 2 - 3 }
\end{tabular}} & \multicolumn{2}{|c|}{ FYM levels } & \multirow{2}{*}{ Mean } \\
\hline $\mathrm{FA}_{0}$ & 4.82 & 4.86 & $\mathbf{4 . 8 4}$ \\
\hline $\mathrm{FA}_{5}$ & 5.15 & 5.38 & $\mathbf{5 . 2 7}$ \\
\hline $\mathrm{FA}_{10}$ & 5.48 & 5.84 & $\mathbf{5 . 6 6}$ \\
\hline $\mathrm{FA}_{15}$ & 5.45 & 5.83 & $\mathbf{5 . 6 4}$ \\
\hline Mean & $\mathbf{5 . 2 2}$ & $\mathbf{5 . 4 8}$ & $\mathbf{5 . 3 5}$ \\
\hline
\end{tabular}

\begin{tabular}{|l|c|c|}
\hline & SEm \pm & CD (0.05) \\
\hline FA & 0.16 & 0.35 \\
\hline FYM & 0.11 & 0.25 \\
\hline FA X FYM & 0.23 & 0.49 \\
\hline
\end{tabular}

\section{Straw yield $\left(\mathrm{t} \mathrm{ha}^{-1}\right)$}

\begin{tabular}{|l|c|c|c|}
\hline \multirow{2}{*}{\begin{tabular}{c} 
Fly ash levels $\begin{array}{c}\text { (t } \\
\left.\text { ha }^{-1}\right)\end{array}$ \\
\cline { 2 - 3 }
\end{tabular}} & \multicolumn{2}{|c|}{ FYM levels } & \multirow{2}{*}{ Mean } \\
\hline $\mathrm{FA}_{0}$ & 6.68 & 6.41 & $\mathbf{6 . 5 4}$ \\
\hline $\mathrm{FA}_{5}$ & 7.12 & 7.65 & $\mathbf{7 . 3 9}$ \\
\hline $\mathrm{FA}_{10}$ & 7.48 & 7.87 & $\mathbf{7 . 6 7}$ \\
\hline $\mathrm{FA}_{15}$ & 7.48 & 7.84 & $\mathbf{7 . 6 6}$ \\
\hline Mean & $\mathbf{7 . 1 9}$ & $\mathbf{7 . 4 4}$ & $\mathbf{7 . 3 2}$ \\
\hline
\end{tabular}

\begin{tabular}{|l|c|c|}
\hline & SEm \pm & CD (0.05) \\
\hline FA & 0.12 & 0.26 \\
\hline FYM & 0.08 & 0.18 \\
\hline FA x FYM & 0.17 & 0.36 \\
\hline
\end{tabular}


Table.2 Effect of fly ash and FYM on number of cracks m-2, mean width of cracks $(\mathrm{cm})$ and mean depth of cracks $(\mathrm{cm})$ in the field after harvest

\begin{tabular}{|l|c|c|c|}
\multicolumn{4}{c}{ Number of cracks $\mathbf{~}^{-2}$} \\
\hline \multirow{2}{*}{$\begin{array}{c}\text { Fly ash levels } \\
\text { ha }^{-1} \text { ) }\end{array}$} & \multicolumn{2}{|c|}{ FYM levels } & \multirow{2}{*}{ Mean } \\
\cline { 2 - 3 } & $\mathrm{FYM}_{0}$ & $\mathrm{FYM}_{10}$ & $\mathbf{8 5 . 3 3}$ \\
\hline $\mathrm{FA}_{0}$ & 96.67 & 74.00 & $\mathbf{5 5 . 5 0}$ \\
\hline $\mathrm{FA}_{5}$ & 54.33 & 56.67 & $\mathbf{4 2 . 5 0}$ \\
\hline $\mathrm{FA}_{10}$ & 46.33 & 38.67 & $\mathbf{3 2 . 6 7}$ \\
\hline $\mathrm{FA}_{15}$ & 36.00 & 29.33 & $\mathbf{5 4 . 0 0}$ \\
\hline Mean & $\mathbf{5 8 . 3 3}$ & $\mathbf{4 9 . 6 7}$ & \\
\hline
\end{tabular}

\begin{tabular}{|l|c|c|}
\hline & SEm \pm & CD (0.05) \\
\hline FA & 5.40 & 11.58 \\
\hline FYM & 3.82 & 8.19 \\
\hline FA x FYM & 7.64 & 16.38 \\
\hline
\end{tabular}

Mean width of cracks $(\mathrm{cm})$

\begin{tabular}{|l|c|c|c|}
\hline \multirow{2}{*}{$\left.\begin{array}{c}\text { Fly ash levels } \\
\text { ha }\end{array}{ }^{-1}\right)$} & \multicolumn{2}{|c|}{ FYM levels } & \multirow{2}{*}{ Mean } \\
\cline { 2 - 3 } & $\mathrm{FYM}_{0}$ & $\mathrm{FYM}_{10}$ & $\mathbf{0 . 9 8}$ \\
\hline $\mathrm{FA}_{0}$ & 0.78 & 1.17 & $\mathbf{1 . 7 2}$ \\
\hline $\mathrm{FA}_{5}$ & 1.67 & 1.77 & $\mathbf{2 . 6 5}$ \\
\hline $\mathrm{FA}_{10}$ & 2.43 & 2.87 & $\mathbf{3 . 6 5}$ \\
\hline $\mathrm{FA}_{15}$ & 3.63 & 3.67 & $\mathbf{2 . 2 5}$ \\
\hline Mean & $\mathbf{2 . 1 3}$ & $\mathbf{2 . 3 7}$ & \\
\hline
\end{tabular}

\begin{tabular}{|l|c|c|}
\hline & SEm \pm & CD (0.05) \\
\hline FA & 0.13 & 0.29 \\
\hline FYM & 0.09 & 0.20 \\
\hline FA x FYM & 0.19 & 0.40 \\
\hline
\end{tabular}

Mean depth of cracks (cm)

\begin{tabular}{|l|c|c|c|}
\hline \multirow{2}{*}{$\begin{array}{c}\text { Fly ash levels } \begin{array}{c}\text { ( } \\
\text { ha }\end{array} \\
\text {-1 }\end{array}$} & \multicolumn{2}{|c|}{ FYM levels } & \multirow{2}{*}{ Mean } \\
\cline { 2 - 3 } & $\mathrm{FYM}_{0}$ & $\mathrm{FYM}_{10}$ & $\mathbf{4 . 1 0}$ \\
\hline $\mathrm{FA}_{0}$ & 3.57 & 4.63 & $\mathbf{5 . 6 0}$ \\
\hline $\mathrm{FA}_{5}$ & 5.40 & 5.80 & $\mathbf{8 . 4 8}$ \\
\hline $\mathrm{FA}_{10}$ & 8.27 & 8.70 & $\mathbf{1 0 . 8 0}$ \\
\hline $\mathrm{FA}_{15}$ & 11.03 & 10.57 & $\mathbf{7 . 2 5}$ \\
\hline Mean & $\mathbf{7 . 0 7}$ & $\mathbf{7 . 4 3}$ & \\
\hline
\end{tabular}

\begin{tabular}{|l|c|c|}
\hline & Sem \pm & CD $(0.05)$ \\
\hline FA & 0.44 & 0.95 \\
\hline FYM & 0.31 & NS \\
\hline FA $x$ FYM & 0.63 & 1.35 \\
\hline
\end{tabular}


Table.3 Effect of fly ash and FYM on per cent aggregates $>0.25 \mathrm{~mm}$ in diameter and mean weight diameter (MWD) of soil after crop harvest

Per cent aggregates $>0.25 \mathrm{~mm}$ diameter

\begin{tabular}{|l|c|c|c|}
\hline \multirow{2}{*}{$\begin{array}{c}\text { Fly ash levels } \\
\text { ha }\end{array}$} & \multicolumn{2}{|c|}{ FYM levels } & \multirow{2}{*}{ Mean } \\
\cline { 2 - 3 } & $\mathrm{FYM}_{0}$ & $\mathrm{FYM}_{10}$ & \\
\hline $\mathrm{FA}_{0}$ & 43.63 & 46.37 & $\mathbf{4 5 . 0}$ \\
\hline $\mathrm{FA}_{5}$ & 43.27 & 51.37 & $\mathbf{4 7 . 3 2}$ \\
\hline $\mathrm{FA}_{10}$ & 44.63 & 53.40 & $\mathbf{4 9 . 0 2}$ \\
\hline $\mathrm{FA}_{15}$ & 45.40 & 55.60 & $\mathbf{5 0 . 5 0}$ \\
\hline Mean & $\mathbf{4 4 . 2 3}$ & $\mathbf{5 1 . 6 8}$ & $\mathbf{4 7 . 9 6}$ \\
\hline
\end{tabular}

\begin{tabular}{|l|c|c|}
\hline & SEm \pm & CD (0.05) \\
\hline FA & 0.61 & 1.31 \\
\hline FYM & 0.43 & 0.93 \\
\hline FA x FYM & 0.87 & 1.86 \\
\hline
\end{tabular}

Mean weight diameter (MWD)

\begin{tabular}{|l|c|c|c|}
\hline \multirow{2}{*}{$\begin{array}{c}\text { Fly ash levels } \\
\text { ha }\end{array}{ }^{-1}$ ( } & \multicolumn{2}{|c|}{ FYM levels } & \multirow{2}{*}{ M ean } \\
\cline { 2 - 3 } & $\mathrm{FYM}_{0}$ & $\mathrm{FYM}_{10}$ & $\mathbf{1 . 8 3}$ \\
\hline $\mathrm{FA}_{0}$ & 1.79 & 1.86 & $\mathbf{1 . 8 5}$ \\
\hline $\mathrm{FA}_{5}$ & 1.79 & 1.90 & $\mathbf{1 . 8 8}$ \\
\hline $\mathrm{FA}_{10}$ & 1.82 & 1.95 & $\mathbf{1 . 8 2}$ \\
\hline $\mathrm{FA}_{15}$ & 1.67 & 1.97 & $\mathbf{1 . 8 4}$ \\
\hline Mean & $\mathbf{1 . 7 7}$ & $\mathbf{1 . 9 2}$ & \\
\hline
\end{tabular}

\begin{tabular}{|l|c|c|}
\hline & SEm \pm & CD (0.05) \\
\hline FA & 0.07 & NS \\
\hline FYM & 0.05 & 0.10 \\
\hline FA x FYM & 0.09 & 0.20 \\
\hline
\end{tabular}


Fig.1 Effect of fly ash levels without FYM on cracking pattern under field conditions
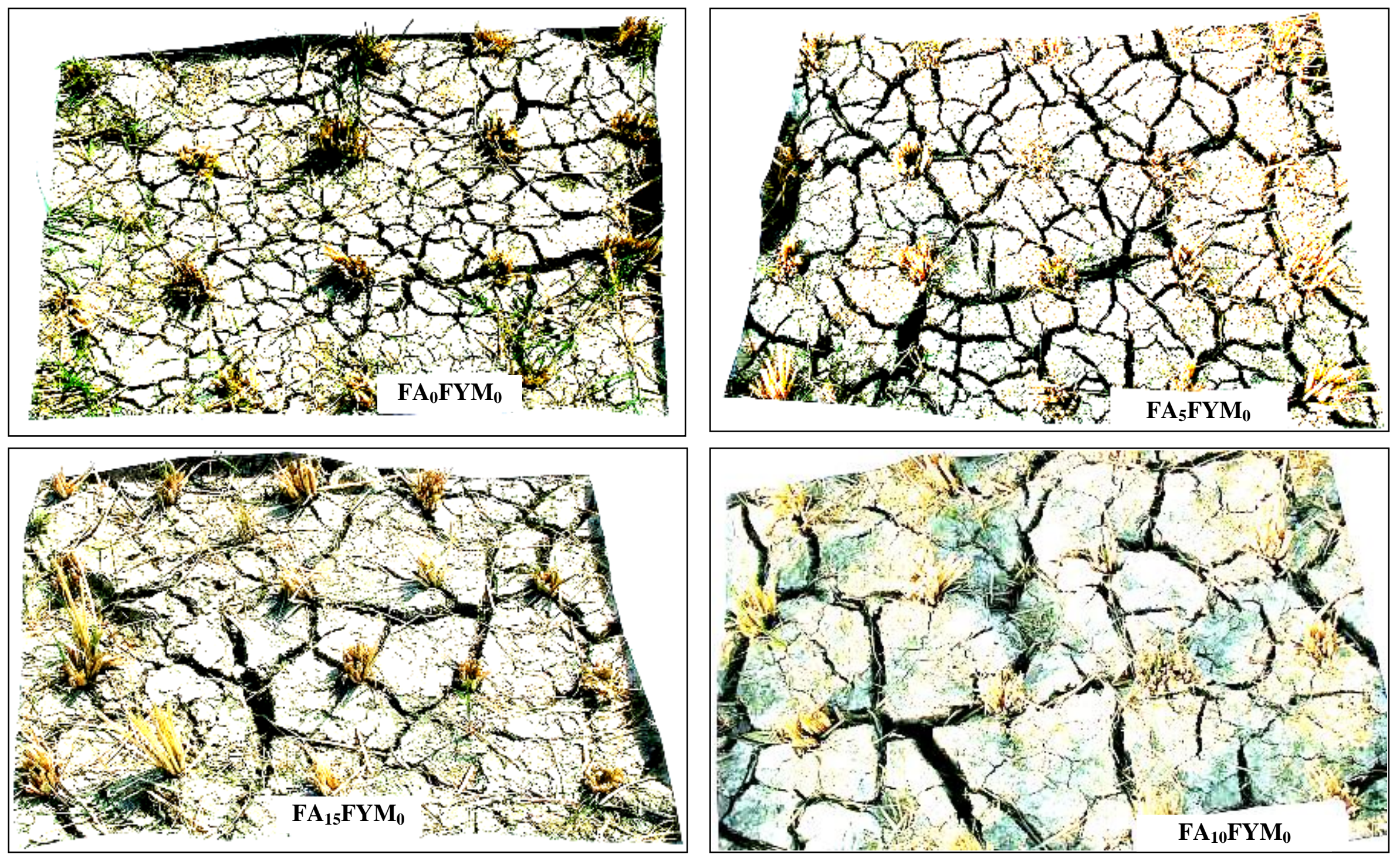
Fig.2 Effect of fly ash levels with FYM (10 t ha-1) on cracking pattern under field conditions
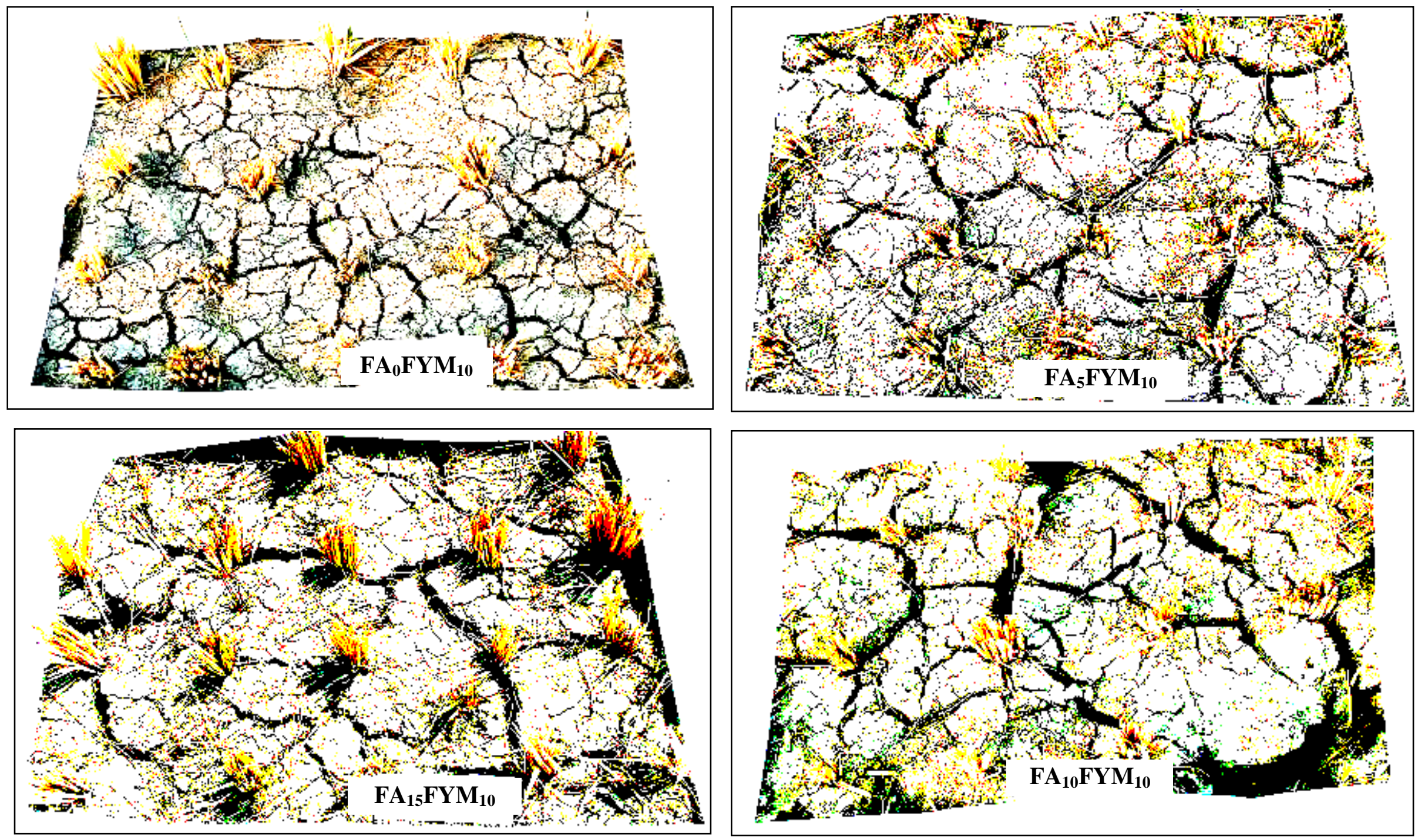
The minimum numbers of cracks were recorded in $\mathrm{FA}_{15}$ FYMo (29.33). Whereas the highest mean width of cracks $(3.67 \mathrm{~cm})$ and the highest mean depth of the cracks (11.03 $\mathrm{cm}$ ) was recorded in $\mathrm{FA}_{15} \mathrm{FYMo}$ compared to $0.78 \mathrm{~cm}$ width and $3.57 \mathrm{~cm}$ depth in control. Thus application of fly ash and FYM has resulted in lesser number of cracks with more width and depth when compared to control. As physically fly ash occurs as a very fine particles having an average diameter $<10 \mathrm{~mm}$ with high surface area, its application might have modified the soil physical environment resulting in deep and wide cracks. Higher proportion of fine particles results in bigger but less number of cracks (Prabhu Prasadini, 1989). The deep and wide cracks in fly ash applied plots decide the water loss from the soil mass particularly from the deeper layers. The quick water loss in coastal areas provides easy tillage operations, which is suitable for growing pulses in coastal areas during Rabi season. So fly ash application reduces submergence in coastal lands and provides drying conditions.

\section{Aggregate stability of soil}

It was studied in terms of per cent of aggregates greater than $0.25 \mathrm{~mm}$ in diameter and mean weight diameter of soil at crop harvest. The treatment $\mathrm{FA}_{15} \mathrm{FYM}_{10}$ has recorded the highest per cent of aggregates > $0.25 \mathrm{~mm}$ in diameter $(55.6 \%)$ followed by $\mathrm{FA}_{10} \mathrm{FAM}_{10}(53.4 \%)$ compared to 43.63 per cent in control (Table 3). The mean weight diameter (MWD) was not significantly influenced by fly ash but was significantly influenced by FYM. Application of FYM at $10 \mathrm{t} \mathrm{ha}^{-1}$ has recorded MWD of 1.92 when compared to 1.77 in FYMo. In general per cent aggregates and MWD was more influenced by FYM application than fly ash application.

Craini (1988) has reported that fly ash had significant effect on MWD. As it is well known that organic manures play role in soil aggregation, there by maintains favorable physicals conditions and supply polysaccharides which are vital for improvement of soil structure. Thus the FYM might have helped in improving the soil aggregate stability.

Study on relationship between aggregate stability and cracking pattern showed that the number of cracks were negatively correlated with per cent aggregates $>0.25 \mathrm{~mm}$ in diameter (-0.55) and MWD (-0.21). However the correlations were not significant. The width of cracks was significantly and positively correlated with MWD (0.81) and depth of cracks was not found to be significantly correlated with per cent aggregates $>0.25 \mathrm{~mm}$ in diameter $(0.47)$ and MWD (0.03).

In conclusion, taking into consideration of grain yield, application of fly ash at $10 \mathrm{t} \mathrm{ha}^{-1}$ along with FYM at $10 \mathrm{t} \mathrm{ha}^{-1}$ is recommended for rice crop grown in Typic Haplustept soils of the Southern Telangana Zone of Andhra Pradesh.

\section{References}

Kumar, A., A.K. Sarkar, R.P. Singh and V. N. Sharma. 1998. Yield and trace metal levels in rice (Oryza sativa) as influenced by fly ash, fertilizer and farmyard manure application. Indian J. of Agricul. Sci., 68(9): 590.

Craini, R.C. 1988. Studies on effect of fly ash on the physical and chemical characteristics of a clay soil. M.Sc Thesis Submitted to Gujarat Agricultural University, Ahmedabad, p.318.

Jeyabal, A., K. Arivazhagan and K. Thanunathan. 2000. Utilization of lignite fly ash as a source of plant nutrient for rice. Fert. News, 45(7): 5558. 
Kemper, W.D. and W.S. Chepil. 1965. Size distribution of aggregates. In $\mathrm{C} A$ Black (Ed.). Methods of soil analysis, Part-I. American Society of Agronomy Incorporation, Madison, USA, pp 499509.

Mongia, A.D., R. Chhabra and K. Lal. 2003. Possibility of using fly ash as a source of silica for increasing rice productivity on a reclaimed alkali soil. J. Indian Soc. of Soil Sci., 51(1): 89-91.

Prabhu Prasadini, P. 1989. Studies on soil structure, dynamics of pore size distribution and water retention and micromorphology with special reference to puddle and swells shrink soils. Ph D Thesis Submitted to Indian Agricultural Research Institute, New
Delhi.

Sahoo, S., and S. Kar. 1998. Effect of fly ash on physical properties of lateritic soil. J. Indian Soc. of Soil Sci., 46(2): 291293.

Selvakumari, G., M. Baskar, D. Jayanthi and K.K. Matham. 2000. Effect of integration of fly ash with. fertilizers and organic manures on nutrient availability, yield and nutrient uptake of rice in Alfisols. J. Indian Soc. Soil Sci., 48(2): 268-278.

Van Bavel, C.H.M. 1949. Mean weight diameter of soil aggregates as a statistical index of aggregation. Soil Sci. Soc. America Proc., 14: 20-23.

\section{How to cite this article:}

Prabhakar Reddy, T., D. Vijaya Lakshmi, J. Kamalakar and Uma Devi, M. 2017. Effect of Fly Ash and Farm Yard Manure on Yield of Rice and Physical Properties of Soil. Int.J.Curr.Microbiol.App.Sci. 6(2): 1525-1533. doi: http://dx.doi.org/10.20546/ijcmas.2017.602.170 